\title{
Exceptional dense water formation on the Adriatic shelf in the winter of 2012
}

\author{
H. Mihanović ${ }^{1}$, I. Vilibić ${ }^{2}$, S. Carniel $^{3}$, M. Tudor ${ }^{4}$, A. Russo ${ }^{5,6}$, A. Bergamasco ${ }^{3}$, N. Bubić ${ }^{2}$, Z. Ljubešić , D. Viličić $^{7}$, \\ A. Boldrin ${ }^{3}$, V. Malačič ${ }^{8}$, M. Celio ${ }^{9}$, C. Comici $^{10}$, and F. Raicich ${ }^{11}$ \\ ${ }^{1}$ Hydrographic Institute of the Republic of Croatia, Split, Croatia \\ ${ }^{2}$ Institute of Oceanography and Fisheries, Split, Croatia \\ ${ }^{3} \mathrm{CNR}$ - Istituto di Scienze Marine, Venice, Italy \\ ${ }^{4}$ Meteorological and Hydrological Service of Croatia, Zagreb, Croatia \\ ${ }^{5}$ DISVA, Università Politecnica delle Marche, Ancona, Italy \\ ${ }^{6} \mathrm{CNR}$ - Istituto di Scienze Marine, Bologna, Italy \\ ${ }^{7}$ Division of Biology, Faculty of Science, University of Zagreb, Zagreb, Croatia \\ ${ }^{8}$ National Institute of Biology, Marine Biological Station, Piran, Slovenia \\ ${ }^{9}$ Regional Environmental Protection Agency - ARPA FVG, Palmanova, Italy \\ ${ }^{10}$ Istituto Nazionale di Oceanografia e di Geofisica Sperimentale - OGS, Trieste, Italy \\ ${ }^{11} \mathrm{CNR}$ - Istituto di Scienze Marine, Trieste, Italy \\ Correspondence to: I. Vilibić (vilibic@izor.hr)
}

Received: 9 November 2012 - Published in Ocean Sci. Discuss.: 6 December 2012

Revised: 17 May 2013 - Accepted: 17 May 2013 - Published: 14 June 2013

\begin{abstract}
In this paper we document dense water formation throughout the Adriatic shelf and coastal area in January/February 2012, resulting in record-breaking densities observed during and after the event. The unprecedented dense water generation was preconditioned by a dry and warm year which resulted in a significant reduction of coastal freshwaters, superimposed on a long-term basin-wide salinity increase. The final event that triggered the dense water formation was an extended period of cold weather with strong and severe winds. Record-breaking potential density anomalies (above $30 \mathrm{~kg} \mathrm{~m}^{-3}$ ) were measured at several formation sites. Accumulated surface net heat and water losses in some coastal regions exceeded $1.5 \mathrm{GJ} \mathrm{m}^{-2}$ and $250 \mathrm{~kg} \mathrm{~m}^{-2}$ over 21 days, respectively. Excessiveness, importance of shelf-type dense water formation and effects on the thermohaline circulation and deep aquatic systems are discussed.
\end{abstract}

\section{Introduction}

Aside from the open-ocean convection type of dense water formation, which has long been recognized to be substantial in driving thermohaline circulation in the global ocean and deep basins, the role of dense water formation over a shelf in changes of deep basins has not been perceived as important until recently (Ivanov et al., 2004; Allen and Durrieu de Madron, 2009; Pattiaratchi et al., 2011). This applies particularly to mid-latitude large and deep basins, such as the Mediterranean Sea, where deep thermohaline circulation is driven by extensive wintertime heat losses and wind mixing at several dense water formation sites (Robinson et al., 2003). Bottom density shelf outflowing currents and dense water cascading are replenishing deep waters, resulting in advection of different water masses and in the change of thermohaline properties in a basin, especially in semi-enclosed seas like the Adriatic Sea (Vilibić et al., 2013).

Although extensively investigated at the Mediterranean sub-basin and process scales (Vilibić and Supić, 2005; Canals et al., 2009; Pasqual et al., 2010), the contribution of the shelf-generated dense water has generally been un- 


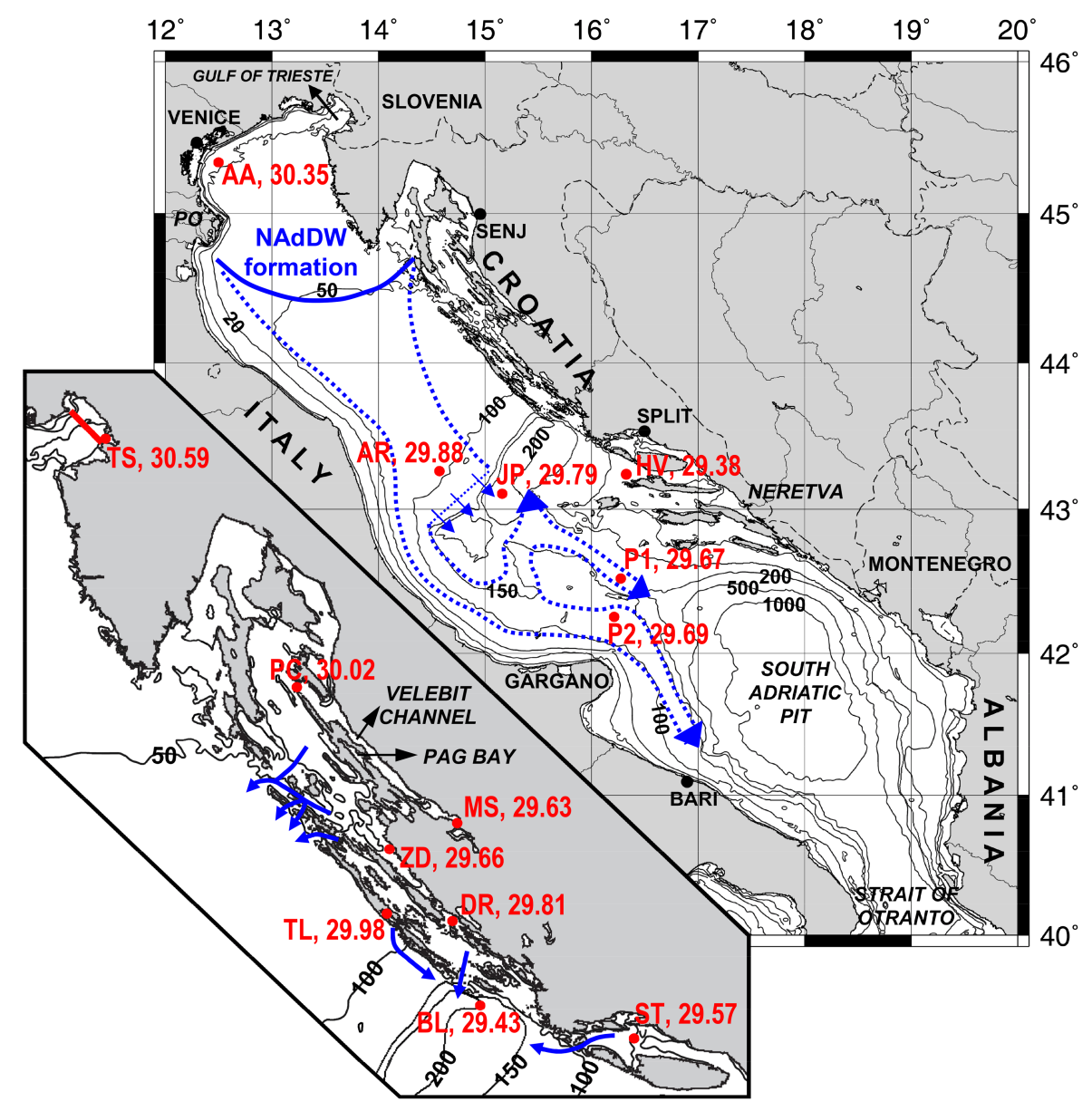

Fig. 1. Adriatic Sea bathymetry, with selected stations at which CTD samplings were carried out between February and April 2012 (main panel: the whole Adriatic; smaller inset: zoom of the eastern Adriatic coastal area). Maximum values of potential density anomalies (in $\mathrm{kg} \mathrm{m}^{-3}$ ) observed at these locations are indicated adjacent to station names. Continuous measurements of meteorological and oceanographic parameters were available at Acqua Alta platform (AA). The red thick line in smaller inset indicates CTD transect used in Fig. 3. The main path of the North Adriatic Dense Water (NAdDW) appears within blue dashed lines in the main panel (adopted from Vilibić et al., 2004). Presumed pathways of dense water generated along the eastern Adriatic coast are denoted by blue arrows in smaller inset.

derrated in the Mediterranean-scale studies, especially within long-term and climate studies (Somot et al., 2006). To be precise, numerical modelling climate studies are still not capable of reproducing shelf dynamics, which is normally occurring at high-resolution spatial and temporal scales and demands mesoscale atmospheric models for forcing (Beg Paklar et al., 2001; Béranger et al., 2010).

The Adriatic Sea (Fig. 1) is a scholar example of both open-convection and shelf types of dense water formation processes, being a result of frequent similar synoptic conditions and wind patterns, mostly related to the blowing of cold and severe bora (ENE or NE) wind (Grisogono and Belušić, 2009). Due to the closeness of shelf and open-ocean dense water formation sites, the formation frequently takes place simultaneously at both places, but not always, as the surface heat losses and preconditioning may differ over the distance of several hundred kilometres (Josey, 2003). The deep-convection site is located in the $1200 \mathrm{~m}$-deep circular South Adriatic Pit characterized by cyclonic circulation and central doming of isopycnals, where vertical mixing during strong dense water formation may reach $800 \mathrm{~m}$ (Gačić et al., 2002). The shelf dense water formation site is located in the northernmost part of the wide Adriatic shelf, having depths less than $50 \mathrm{~m}$, where strong bora cools the entire water column (Pullen et al., 2007; Jeffries and Lee, 2007). Generated dense waters (North Adriatic Dense Water (NAdDW); e.g. Zore-Armanda, 1963; Bergamasco et al., 1999; Vilibić and Supić, 2005) flow as a dense current along the western Adriatic shelf, replacing old waters in the middle and south Adriatic depressions (Jabuka Pit and South Adriatic Pit, respectively; Fig. 1; see Vilibić et al., 2004; Vilibić and Mihanović, 2013). NAdDW partly transforms into Adriatic Dense Water (AdDW) during deep-convection processes in the south Adriatic, and both AdDW and modified NAdDW 
subsequently flow out of the Adriatic through the Strait of Otranto, sinking to the Ionian deep layers and affecting the whole deep Eastern Mediterranean (Robinson et al., 2003). The Otranto Strait outflowing fraction of the NAdDW is estimated to be about $10 \%$ of the AdDW during average years (Vilibić and Orlić, 2002).

The dense water outflow from the Adriatic is compensated by the advection of saltier Levantine Intermediate Water (LIW) from the Ionian Sea, which affects circulation and dense water formation in the middle and north Adriatic. It is suggested that the interaction between the Ionian and the Adriatic is changing on a decadal scale by means of the Bimodal Oscillating System (BiOS) mechanism (Gačić et al., 2010), an internally driven process related to decadal variation of the upper-layer circulation in the Ionian, from cyclonic to anticyclonic and vice versa. The mechanism influences the intrusion of LIW in the Adriatic (stronger intrusions during the cyclonic phase) and affects the dense water properties in the South Adriatic Pit and biogeochemical properties of the whole system (Civitarese et al., 2010). Conversely, the changing properties of outflowing AdDW eventually modify the upper-layer circulation in the Ionian and the pathways of water masses, thus impacting the entire Levantine basin (Gačić et al., 2011).

Multi-decadal monitoring efforts along the dense water formation area and several campaigns that captured very dense bottom currents have documented maximum potential density anomaly $\left(\sigma_{\theta}\right)$ in the open northern Adriatic not exceeding $30 \mathrm{~kg} \mathrm{~m}^{-3}$ (e.g. between 1967 and 2000, as given by Supić and Vilibić, 2006). However, it seems that higher densities may be reached quite close to the coast, during severe winters occurring over centurial timescales. Namely, Vatova (1934) documented the temperature of $3.95^{\circ} \mathrm{C}$ and salinity equaling 38.15 at $22 \mathrm{~m}$ depth off Koper (Gulf of Trieste, Fig. 1), during the severe winter of 1929, resulting in potential density anomaly of $30.30 \mathrm{~kg} \mathrm{~m}^{-3}$. Harsh winter conditions caused mass mortality of benthic organisms at the time. Still, this almost $100 \mathrm{yr}$-old measurement is the only historical record with such a high density in the north Adriatic. The record was broken during a long and severe bora episode in the winter of 2012, which is documented in this study.

This paper presents the first detailed documentation of the dense water formation that occurred in the north and middle Adriatic during the winter of 2012. The episode was preconditioned by a very dry year, and the shelf and coastal dense water formation occurred not only in the classical sites but also in a number of eastern Adriatic coastal channels and bays, where dense water formation has not been documented to this day due to large freshwater load. The study is based on meteorological and oceanographic measurements available before and after the event in both coastal and open Adriatic waters (particularly conductivity, temperature and depth (CTD) campaigns). It also quantifies atmospheric forcing and ocean dynamics reproduced by operational atmospheric and ocean models, including an assessment of the precondi- tioning and raising a discussion on meteorological conditions and implications that are connected with the extreme cooling event.

\section{Data and methods}

\subsection{Field campaigns and data processing}

A number of oceanographic field campaigns ( 8 in total) were carried out in the coastal and open Adriatic waters between February and April 2012, some of them being a part of regular monitoring activities and some of them organized ad hoc after the prolonged bora episode in January/February 2012 (Fig. 1). CTD measurements in the Gulf of Trieste, which are normally carried out on a monthly basis, were conducted immediately after cessation of the strong wind, between 14 and 16 February 2012, at 44 stations. CTD measurements in Pag Channel were organized ad hoc on 29 March 2012 and encompassed 3 stations (including the PC station). CTD measurements in Telašćica Bay (TL) were conducted on 29 February 2012, encompassing 6 stations within the bay, while measurements in the Drage (DR) region at 16 stations and at the BL station were organized on 28 February 2012, as a part of a sewage system ecological study. CTD stations MS and ZD were surveyed from 27 to 29 March 2012, being a part of a Croatian coastal waters monitoring programme (15 stations altogether). Finally, regular CTD samplings between Split and Gargano at a number of CTD stations were carried out on 21-23 February, 14-16 March and 25-27 April 2012 (including stations ST, HV, P1, P2 and JP), being a part of a 60 yr climate monitoring programme (Vilibić et al., 2013). All CTD probes used in the field survey (Seabird SBE 19 and SBE 25, Idronaut 316, Sea\&Sun MSS90) have been regularly calibrated, with an accuracy of at least $\pm 0.01^{\circ} \mathrm{C}$ for temperature and \pm 0.005 for practical salinity.

Also, vertical thermohaline profiles were measured every 5 days by an ARGO float stacked in the Jabuka Pit for more than a year (code 1900848, available at http://www.coriolis. eu.org). The bottom density current associated with the dense water formation measured in the winter of 2012 by the float was analysed in detail by Vilibić and Mihanović (2013); in this paper we present the highest measured density and associated temperature and salinity values observed by the float (AR in Fig. 1 and Table 1). In general, Fig. 1 contains the locations of the most interesting vertical profiles and thermohaline observations, and the highest potential density anomalies observed in 2012. Corresponding dates, depths, potential temperatures and practical salinities are given in Table 1.

Continuous sampling of temperature and practical salinity has been conducted off Venice, at the Acqua Alta platform, located in a $16 \mathrm{~m}$-deep area (AA in Fig. 1). Hydrolab DS5X multiparameter sensors were located at the surface and near the bottom (at $2 \mathrm{~m}$ and $13 \mathrm{~m}$ ), with a sampling rate of $30 \mathrm{~min}$ and an accuracy of $\pm 0.1^{\circ} \mathrm{C}$ for temperature 
Table 1. Sampling dates, depths, potential temperatures $(\theta)$ and practical salinities corresponding to the potential density anomaly data presented in Fig. 1.

\begin{tabular}{lrrrr}
\hline Station & Date in 2012 & Depth $(\mathrm{m})$ & $\theta\left({ }^{\circ} \mathrm{C}\right)$ & $\mathrm{S}$ \\
\hline TS (Gulf of Trieste) & $15 \mathrm{Feb}$ & 18.0 & 4.237 & 38.556 \\
AA (Acqua Alta) & $11 \mathrm{Feb}$ & 13.0 & 6.351 & 38.600 \\
PC (Pag Channel) & $29 \mathrm{Mar}$ & 101.1 & 9.363 & 38.772 \\
TL (Telašćica) & $29 \mathrm{Feb}$ & 34.3 & 9.154 & 38.683 \\
AR (Argo 1900848) & $04 \mathrm{Apr}$ & 96.0 & 9.540 & 38.638 \\
DR (Drage) & $28 \mathrm{Feb}$ & 29.0 & 10.282 & 38.717 \\
JP (Jabuka Pit) & $27 \mathrm{Apr}$ & 266.0 & 10.004 & 38.633 \\
P2 (Palagruža Sill) & $16 \mathrm{Mar}$ & 130.0 & 10.579 & 38.638 \\
P1 (Palagruža Sill) & $26 \mathrm{Apr}$ & 171.0 & 10.933 & 38.695 \\
ZD (Zadar) & $27 \mathrm{Mar}$ & 30.0 & 11.527 & 38.825 \\
MS (Maslenica) & $29 \mathrm{Mar}$ & 24.5 & 6.948 & 37.790 \\
ST (Split Channel) & $21 \mathrm{Feb}$ & 47.5 & 10.937 & 38.559 \\
BL (Blitvenica) & $28 \mathrm{Feb}$ & 196.5 & 11.995 & 38.642 \\
HV (Hvar) & $21 \mathrm{Feb}$ & 72.5 & 12.231 & 38.642 \\
\hline
\end{tabular}

and \pm 0.2 for salinity. The data were quality checked and calibrated by vertical profiles obtained every 30 days with an IDRONAUT Ocean Seven 316 CTD probe (accuracy of $\pm 0.003^{\circ} \mathrm{C}$ for temperature and \pm 0.003 for salinity). Wind speed and direction, air pressure, temperature and humidity data were sampled every $30 \mathrm{~min}, 15 \mathrm{~m}$ above sea level. Latent and sensible fluxes at AA platform were computed using the COARE 4.0 algorithm, following the methodology given by Edson (2009). Also, continuous sea temperature measurements were performed in the central part of the Gulf of Trieste (Paloma pillar, located $10 \mathrm{~km}$ to the west of station TS), at depths of 3,15 and $24 \mathrm{~m}$ (sea floor depth is $25 \mathrm{~m}$ ) with SIAP-MICROS Pt100 sensors (accuracy $\pm 0.1^{\circ} \mathrm{C}$ ).

Potential temperatures and potential density anomalies (reference pressure equalling zero) were computed from temperature and practical salinity data, following TEOS-10 algorithms and using scripts available at http://www.teos-10.org.

\subsection{Operational numerical models}

Two operational numerical models were used to quantify the processes at the air-sea interface. The first is the numerical weather prediction (NWP) ALADIN/HR model, and the second is the COSMO/ROMS (Consortium for Smallscale Modelling / Regional Ocean Modeling System) oneway coupled system. The first model has been taken into analysis as it has fine-scale orography and parameterization adapted for the complex eastern Adriatic karstic area and steep orography. Therefore, it is expected to have better reproduction of atmospheric processes in this part of the Adriatic, including heat and water fluxes. The second model is composed of another NWP model (COSMO) and a hydrodynamic oceanographic model (ROMS); COSMO/ROMS has been developed for processes in the open and western Adri- atic Sea, but it is not fully adapted for the eastern Adriatic complex orography and bathymetry.

NWP ALADIN/HR model is operationally used by the Meteorological and Hydrological Service of Croatia. The operational model forecast is run once a day in $2 \mathrm{~km}$ horizontal resolution on 37 levels in the vertical using non-hydrostatic dynamics and a full set of physics parameterizations (Tudor and Ivatek-Šahdan, 2010). It is initialized daily from the $6 \mathrm{~h}$ ALADIN forecast run in $8 \mathrm{~km}$ resolution using the scale-selective digital filter initialization (Termonia, 2008). Sea surface temperature (SST) in the model is provided by the global atmospheric model ARPEGE and does not change during the $24 \mathrm{~h}$ model run. Turbulent fluxes are computed as turbulent exchange between the lowest model level (around $17 \mathrm{~m}$ above the sea surface) and the sea surface. The turbulent exchange coefficients are computed using prognostic turbulent kinetic energy values. Fluxes of water substance, momentum and heat due to turbulence, radiation, evaporation, precipitation and other physical processes are computed and stored in the output files and archived operationally with a $1 \mathrm{~h}$ interval. The fields used in this study are retrieved from the operational archive, and time series of the fluxes are computed for the areas of interest together with accumulated budgets through the whole period.

COSMO/ROMS has been defined as a one-way coupled system because atmospheric fields provided by the NWP COSMO are combined with SST produced by ROMS to derive air-sea fluxes which are then used by the ROMS, but not by the COSMO. The utilized COSMO-I7 is an Italian operational implementation of the COSMO model (http://www. cosmo-model.org; Italian partners are USAM of the Italian Air Force, the Environmental Protection Agency of Piemonte Region, Italy, and the Emilia Romagna Regional Agency for Protection and Environment, ARPA-ER, Italy), a limitedarea non-hydrostatic atmospheric prediction model derived 
from the Lokal Model (Steppeler et al., 2003). COSMO-I7 covers a wide domain (roughly $33-50^{\circ} \mathrm{N}$ and $0-24^{\circ} \mathrm{E}$ ) centred over Italy with $7 \mathrm{~km}$ horizontal resolution; it has been operational since 2001 at the Hydro-Meteo-Clima Service (SIMC) of the ARPA-ER in Bologna, providing $72 \mathrm{~h}$ forecasts twice a day (at 00:00 and 12:00 UTC), archived at hourly intervals. COSMO-I7 boundary conditions are provided by the ECMWF IFS system (http://www.ecmwf.int/ research/ifsdocs), and initial fields for each run are obtained with a "nudging" data assimilation technique. The Regional Ocean Modeling System (ROMS,http://www.myroms.org) is a primitive equation, with finite differences, hydrostatic, free surface model, and tides included. The utilized Adriatic ROMS application is operational both at DISVA and SIMC (a description of the system can be found in Chiggiato and Oddo, 2008, and Russo et al., 2009; it has been updated in 2011), and it has a constant resolution of $2 \mathrm{~km}$ across the entire domain and 20 stretched vertical sigma levels. Forty-nine rivers and karstic springs (the latter located in the eastern coastal area) were also included as sources of mass and momentum, using real-time daily discharges for the Po River and monthly climatological values for other freshwater sources. Radiation condition is imposed at the Strait of Otranto with a nudging of mean daily forecast of temperature, salinity, and baroclinic currents from the general circulation model of the Mediterranean Ocean Forecasting System (Oddo et al., 2009), provided by MyOcean (www.myocean.eu). Fluxes through the air-sea interface are calculated using the COARE 3.0 bulk flux algorithms (Fairall et al., 2003), with SST from ROMS and short-wave radiation, wind, air temperature, humidity, cloud cover and atmospheric pressure from the COSMO-I7 atmospheric model forecasts.

We should emphasize that the dynamics of inner Croatian channels and embayments may not be properly reproduced by the presented COSMO/ROMS model as (i) the model resolution is not sufficient to resolve the bathymetry features (e.g. Velebit Channel, where heat/water losses were the highest, is about $100 \mathrm{~km}$ long and just $2-7 \mathrm{~km}$ wide, while there are dozens of inlets and channel connections, such as TL, which are just from a few hundreds metres to $2 \mathrm{~km}$ wide), and (ii) freshwater fluxes are not introduced properly to the model, due to insufficient knowledge on numerous karstic submarine spring discharges in the area. Also, east Adriatic rivers do not have easily available discharge measurements, and research and operational ocean systems normally use climatological values (e.g. Oddo and Guarnieri, 2011). However, this was far from the real situation in 2012 due to the prolonged dry period (see Sect. 3), and the operational model was probably introducing too large of a freshwater load in this area.

\section{Results and discussion}

\subsection{Observations in the winter of 2012}

Maximum potential density anomaly records and tabulated respective potential temperatures, salinities and dates of measurements taken in the north and middle Adriatic between February and April 2012 (after the extreme cold event and severe bora outbreak) are shown in Fig. 1 and Table 1. The bora episode lasted for about 3 weeks in the coastal eastern Adriatic region, between 25 January and 14 February 2012. Wind was strong to severe from ENE to NE, blowing occasionally with hurricane force. The maximum potential density anomalies were measured throughout the Gulf of Trieste, with absolute maximum at the TS station sampled on 15 February (30.59 $\mathrm{kg} \mathrm{m}^{-3}$ at $18 \mathrm{~m}$ depth). During the field study carried out in the gulf between 14 and 16 February 2012 , potential density anomaly surpassed $30.50 \mathrm{~kg} \mathrm{~m}^{-3}$ at 25 CTD stations out of 44 . The absolute temperature minimum below $20 \mathrm{~m}$ was observed at $24 \mathrm{~m}$ depth on the Paloma pillar, in the central part of the gulf $\left(3.9^{\circ} \mathrm{C}\right)$, during the mornings of 13 and 15 February 2012. This temperature record is quite similar to the bottom temperature observed by Vatova (1934) in the winter of $1929\left(3.95^{\circ} \mathrm{C}\right.$ at $\left.22 \mathrm{~m}\right)$.

Slightly lower potential density anomalies were measured at the AA oceanographic platform on 11 February $\left(30.35 \mathrm{~kg} \mathrm{~m}^{-3}\right)$. The platform is located at the margin of the bora-driven northern Adriatic gyre, in which a peak of dense water formation is normally located (Boldrin et al., 2009). Such densities are much higher than those previously recorded in the area over an extended period of time (e.g. 1967-2000; Supić and Vilibić, 2006), driven both by extremely high salinities $(>38.5)$ and very low temperatures $\left(<6.5^{\circ} \mathrm{C}\right)$. Another potential density anomaly maximum was measured at the $100 \mathrm{~m}$-deep Pag Channel station (PC), located deep inside Croatian inner waters $\left(30.02 \mathrm{~kg} \mathrm{~m}^{-3}\right)$. Exceptionally high salinities (around 38.77) were recorded at the station, and these salinities are even higher than the average value documented for the south Adriatic (Artegiani et al., 1997a). Finally, extremely high salinities, low temperatures and associated high density anomalies were recorded along the entire eastern Adriatic coastal area northwest from Split, all above $29.55 \mathrm{~kg} \mathrm{~m}^{-3}$. Such values have never been documented before in this part of the Adriatic (e.g. Zore-Armanda et al., 1991).

Vertical profiles at selected stations (Fig. 2) show a variety of processes that occurred during the winter of 2012. The difference between September 2011 and February 2012 vertical profiles at the Jabuka Pit station (JP) exhibits vertical homogenization and deep convection that occurred at least down to $150 \mathrm{~m}$ during the bora event (Fig. 2a). Further on, between February and April 2012 cruises, the temperature below $180 \mathrm{~m}$ decreased by more than $2.5^{\circ} \mathrm{C}$, while salinity had a slight decrease (0.06-0.08), resulting in additional density anomaly increase by up to $0.45 \mathrm{~kg} \mathrm{~m}^{-3}$. The changes visible 

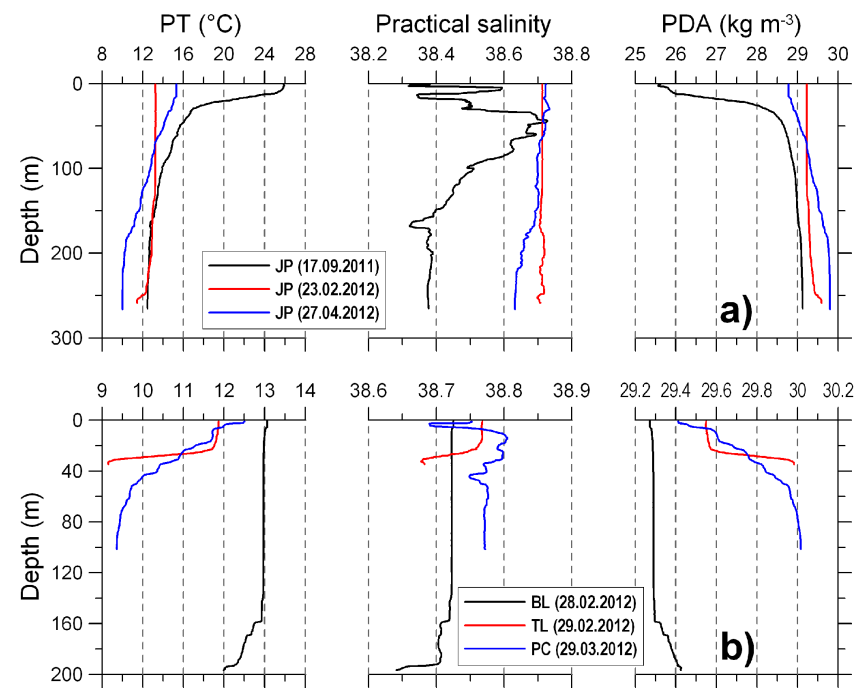

Fig. 2. Vertical profiles of potential temperature, practical salinity and potential density anomaly at selected stations along the eastern Adriatic coast: (a) JP on 17 September 2011, 23 February 2012 and 27 April 2012; (b) BL on 28 February 2012, TL on 29 February 2012 and PC on 29 March 2012.

near the bottom in February and below $80 \mathrm{~m}$ in April 2012 are footprints of dense water arrival from the "classical" north Adriatic dense water formation site and/or from the eastern Adriatic inner waters.

The maximum recorded potential density anomalies in the inner Croatian waters (Fig. 2b) largely exceeded those observed just after the event in the open middle Adriatic (Jabuka Pit, Palagruža Sill), which ranged around 29.2$29.3 \mathrm{~kg} \mathrm{~m}^{-3}$ (not shown). This implies the existence of a density current flowing through deep connecting channels of the eastern Adriatic, most of them transporting dense water to the Jabuka Pit (arrows in smaller inset in Fig. 1, showing the eastern Adriatic area and presumed pathways of dense water). Indeed, a strong drop in temperature and a slight decrease in salinity were observed at the bottom of the BL station on 28 February 2012 (Fig. 2b; one should note that the BL station is about $200 \mathrm{~m}$ deep, while the depression $10 \mathrm{~km}$ to the west of $\mathrm{BL}$ is $237 \mathrm{~m}$ deep, but no measurements were taken there). As there was almost no possibility for dense water to reach the BL station from the north Adriatic 15 days after the dense water formation (Vilibić and Supić, 2005), the most likely explanation is that these waters came from the inner Croatian sea. To confirm this, however, further quantitative analysis and estimation of the dense water formation rates along the eastern Adriatic coast should follow through process-oriented numerical modelling exercises with highresolution bathymetry and real freshwater discharges.

Particularly interesting is the density anomaly measured at the TL station, located in the middle of a $10 \mathrm{~km}$-long island embayment connected to the open Adriatic (Telašćica Bay, Dugi Otok Island). Two weeks after the event the ma-
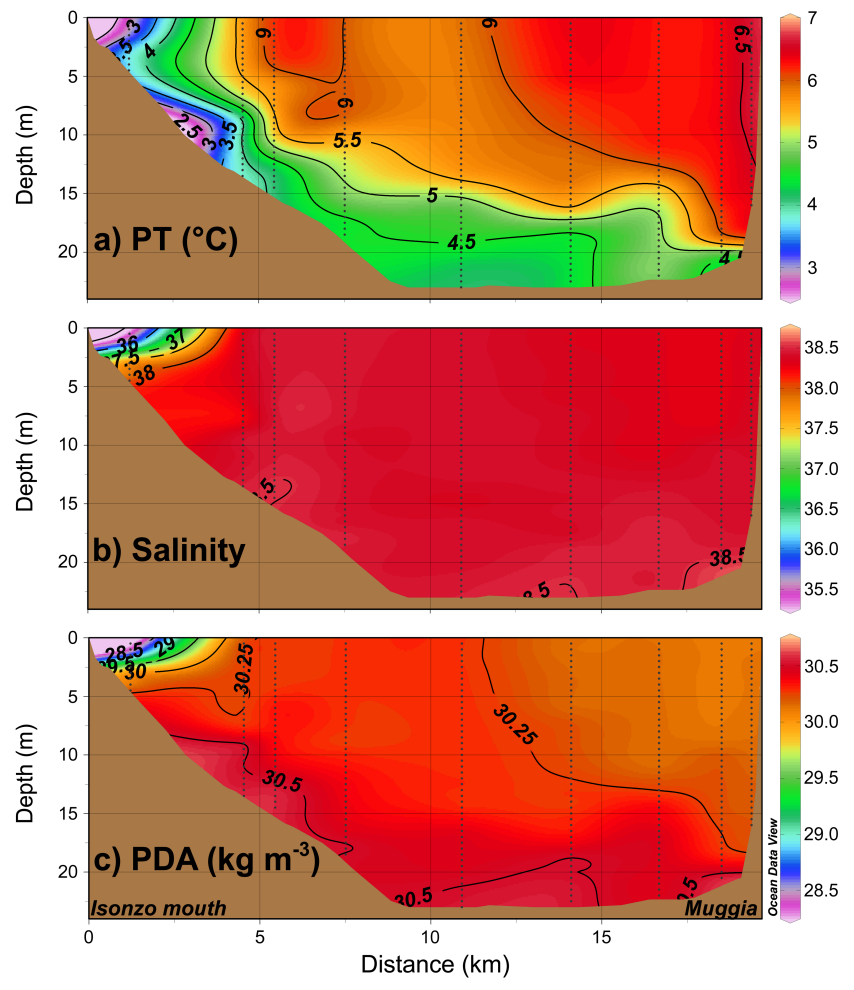

Fig. 3. Distribution of (a) potential temperature (PT, in ${ }^{\circ} \mathrm{C}$ ), (b) practical salinity and (c) potential density anomaly (PDA, in $\mathrm{kg} \mathrm{m}^{-3}$ ) measured in the Gulf of Trieste between 14 and 16 February 2012. The mouth of the Isonzo River is at the northwestern part of the transect. See the smaller inset in Fig. 1 for transect position.

jority of the embayment was homogenized, except for the deepest parts, where very cold and slightly less saline waters were observed, with potential density anomaly equalling $29.98 \mathrm{~kg} \mathrm{~m}^{-3}$. As the TL station is located in a depression within the embayment, which is separated from the outer parts of the bay by an $8 \mathrm{~m}$-high ridge, the captured bottom dense waters represent a footprint of dense water formation that occurred a few weeks before. These waters then rapidly left the embayment as a density current over a slope, towards the northern parts of the deep Jabuka Pit, and presumably reached its northernmost depression, to the west of the $\mathrm{BL}$ station (vertical profile similar to TL was observed at the DR station).

The highest potential density anomalies were recorded in the Gulf of Trieste (Fig. 3). The potential density anomaly exceeded $30.0 \mathrm{~kg} \mathrm{~m}^{-3}$ throughout the gulf, except at the very mouth of the Isonzo River. Maximum densities were measured along the bottom slope of the northwestern part and in the deepest central part of the gulf (above $30.5 \mathrm{~kg} \mathrm{~m}^{-3}$ ), being a result of extremely low temperatures $\left(<4.7^{\circ} \mathrm{C}\right)$ and high salinities (38.4-38.5).

Time series of potential temperature, salinity and potential density anomaly observed at the AA station (Fig. 4) document the severity of the event and also the evolution of 
characteristics. During the episode the entire water column mixed, water cooled down by about $4^{\circ} \mathrm{C}$ (to $5.8-6.5^{\circ} \mathrm{C}$ ), while salinity surpassed 38.5 (since less saline surface waters were restricted to the very edge of the coast during the bora), resulting in density anomalies higher than $30 \mathrm{~kg} \mathrm{~m}^{-3}$. That was a result of strong cooling at the surface, as turbulent heat flux series computed for AA (Fig. 4d) denote the cooling with two pronounced maxima: the first stronger one occurred on 3 February with maximum heat losses up to $800 \mathrm{~W} \mathrm{~m}^{-2}$, while the second maximum was observed on 11 February, with heat losses reaching $700 \mathrm{~W} \mathrm{~m}^{-2}$. However, the AA station is not positioned in the area with the strongest cooling; heat fluxes at AA are found to be 3-4 times lower than in the bora maximum jets stretching from several locations at the eastern shore (Pullen et al., 2007).

\subsection{Model estimates}

Turbulent heat fluxes from both models followed those computed via bulk formulae using meteorological and oceanographic data acquired at the AA tower. During intense heat loss episodes, COSMO/ROMS overestimated the fluxes by about $10 \%$, while ALADIN/HR underestimated them by about $14 \%$ on average. Nevertheless, temporal changes and peak values were reproduced well by both models, as can be observed in Fig. 4a.

Spatial distribution of modelled fluxes, represented in Fig. 5 as a cumulative energy and mass loss during the bora episode (25 January-14 February 2012), quantifies the amount of energy and mass taken from the sea and indicates jets with extreme energy losses due to cold and severe bora wind. The energy loss (Fig. 5a) exceeded $1.5 \mathrm{GJ} \mathrm{m}^{-2}$ over the maximum bora jet along the eastern shore (off Senj), which is equivalent to a cooling rate of about $4.5^{\circ} \mathrm{C}$ over the whole event, if the box model heat balance approach over $80 \mathrm{~m}$ deep ocean (average sea depth over the bora jet areas in the inner Croatian waters) is used (Gill, 1982). The box model neglects lateral input as acting on longer timescales than the atmospheric forcing, which is a fair approximation for preliminary computations. Naturally, similar energy losses over smaller and shallower embayments, e.g. Pag Bay ( $40 \mathrm{~m}$ average depth), would multiply the cooling of the ocean. Lower cooling rates over the shallower northern Adriatic would yield a similar temperature decrease. The energy loss of $0.7 \mathrm{GJ} \mathrm{m}^{-2}$ modelled over the 30-40 m-deep TL embayment would decrease the temperature by about $5{ }^{\circ} \mathrm{C}$. Similar rates were estimated for the Gulf of Trieste and confirmed by temperature measurements from the buoys in the gulf. Lower heat losses occurred over the open-convection deep water formation area in the south Adriatic, where bora did not blow during the whole period and therefore relatively modest cooling and vertical mixing were observed (up to $500 \mathrm{~m}$, not shown).

In addition to the cooling, cumulative water loss (Fig. 5b) during the event surpassed $250 \mathrm{~kg} \mathrm{~m}^{-2}$ over the maximum

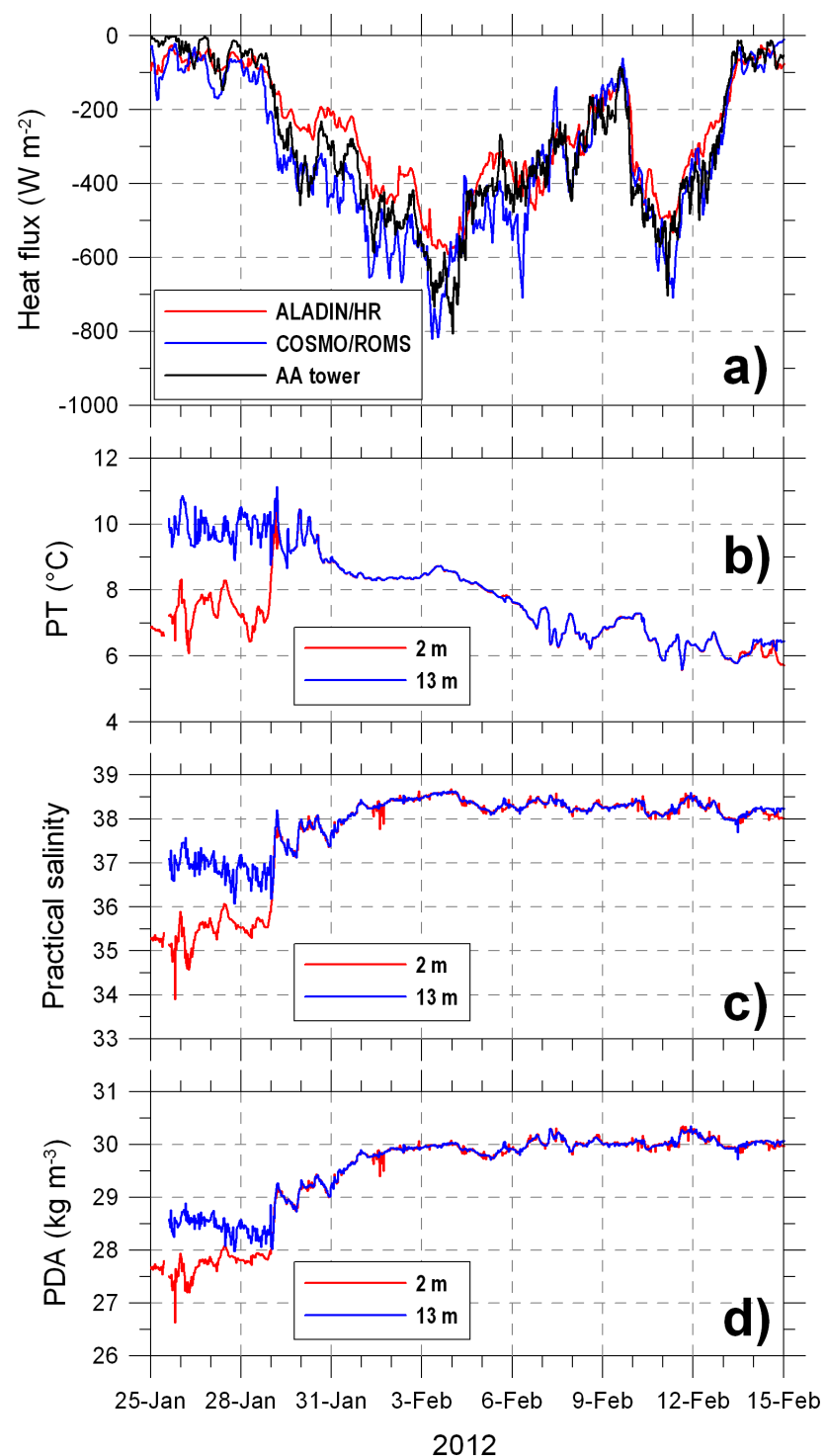

Fig. 4. (a) Time series of turbulent heat fluxes (negative values denote heat loss from the sea) estimated from measurements for station AA (black), together with modelled heat fluxes computed by ALADIN/HR (red) and COSMO/ROMS (blue) models at the grid point nearest to AA, for the period between 25 January and 14 February 2012. Time series of surface $(2 \mathrm{~m})$ and bottom $(13 \mathrm{~m})$ (b) potential temperature (PT), (c) practical salinity and (d) potential density anomaly (PDA) during the same period at the AA station.

bora jet, being equivalent to a salinity increase of 0.12 over the $80 \mathrm{~m}$-deep inner Croatian waters. Cumulative water losses were 2-3 times lower over the classical dense water formation site in the northern Adriatic, resulting in a slightly lower salinity increase rate (about 0.1 ). By using a box model, potential density anomaly increase can be estimated at around $0.95 \mathrm{~kg} \mathrm{~m}^{-3}$ in the inner Croatian waters. 


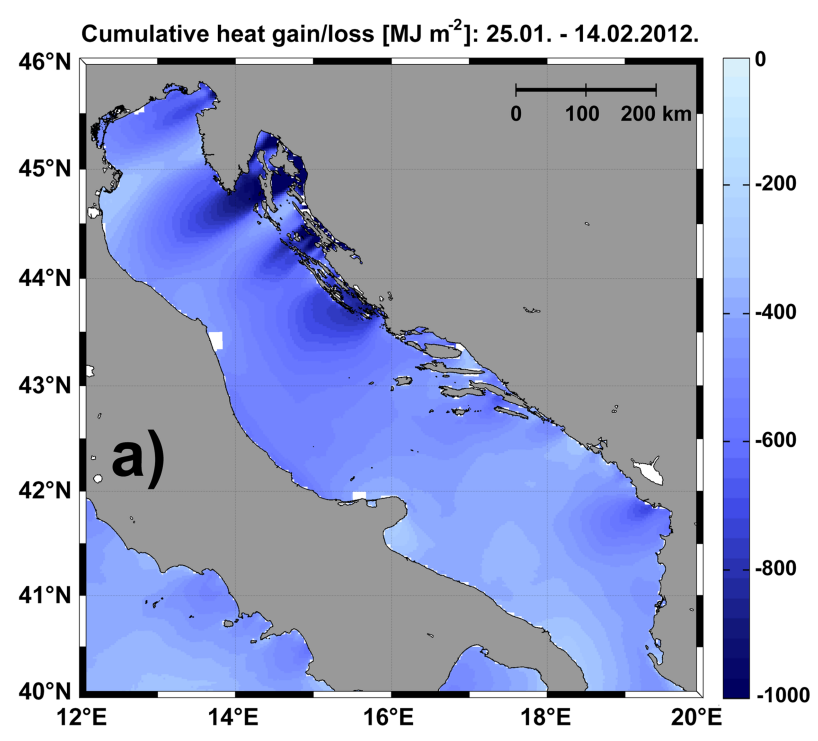

Cumulative water gain/loss $\left[\mathrm{kg} \mathrm{m}^{-2}\right]: 25.01$. - 14.02.2012.

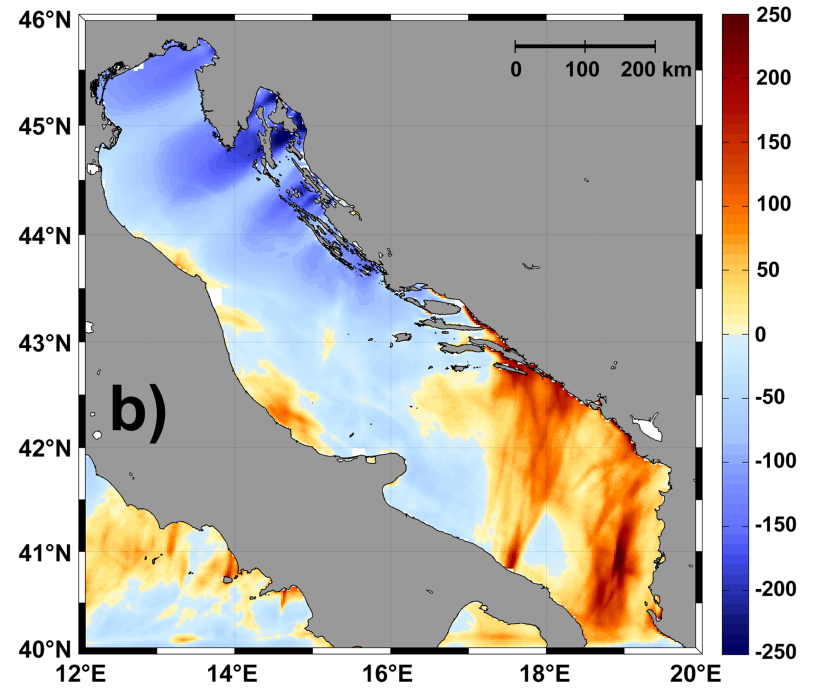

Fig. 5. Cumulative (a) heat and (b) water gain/loss between 25 January and 14 February 2012 as estimated by the ALADIN/HR model. Negative values denote heat and water losses from the sea.

Outputs of the COSMO/ROMS numerical model (which, differently than the box model, includes lateral advection) were analysed in order to estimate the total volume of NAdDW generated during the event. In mid-February, just after the end of the cooling episode, the total volume of the generated NAdDW exceeding the density threshold of $29.5 \mathrm{~kg} \mathrm{~m}^{-3}$ equalled $4250 \mathrm{~km}^{3}$. The generated NAdDW encompassed most of the northern and a large part of the middle Adriatic. By assuming that the associated dense water current (flowing southeast) lasts for 3 months, one may reach a preliminary estimate of average transport of $0.55 \mathrm{~Sv}$. This is several times larger than documented during previous dense water formation years. Artegiani and Salusti (1987) estimated with a streamtube model the NAdDW flux of $0.02 \mathrm{~Sv}$ during dense water formation in 1981, while Mantziafou and Lascaratos (2004) modelled a NAdDW production yearly rate of $0.03-0.04 \mathrm{~Sv}$ (i.e. $0.12-0.16 \mathrm{~Sv}$ in 3 months), and Artegiani et al. (1997b) documented a NAdDW yearly rate of $0.07 \mathrm{~Sv}$ (i.e. 0.28 in 3 months), both looking at a time span covering several decades. However, the last two estimates are based on a much lower density threshold of $29.2 \mathrm{~kg} \mathrm{~m}^{-3}$, which is more appropriate for average dense water formation rates. We choose a higher threshold than previous studies to take into account lower temperatures (about $1{ }^{\circ} \mathrm{C}$ ) and higher salinities (about 0.1 in offshore areas) forecasted by COSMO/ROMS in the northern Adriatic Sea. At the beginning of January 2012 (before the dense water formation event) waters having densities above $29.5 \mathrm{~kg} \mathrm{~m}^{-3}$ occupied a volume of $218 \mathrm{~km}^{3}$, corresponding to the average volume of dense water stored in the Jabuka Pit year round (Artegiani et al., 1997b), so the chosen threshold can be considered as a conservative one. Conclusively, both formation rates and associated densities were much higher during the winter of 2012 than during normal dense water formation years.

It should be emphasized that real volumes were probably larger, as the model did not recognize the eastern Adriatic coastal waters as an area where high densities were present after the outbreak. To be precise, climatological freshwater load resulted here in much lower modelled salinities with respect to the observed ones, the difference ranging between 0.4 and 1.5 .

The highest densities estimated by the model were obtained in the northernmost part of the Adriatic shelf. This area has already been recognized as the place where the densest waters have been normally formed (e.g. Vilibić and Supić, 2005). Once generated, the water rapidly propagated towards the middle Adriatic and reached the western Jabuka Pit perimeter a few days after the cessation of severe winds and dense water production (the cooling event ended on 14 February). The pathway followed the western Adriatic shelf (see the scheme in Fig. 1), as already documented by previous studies (Vilibić et al., 2004; Vilibić and Mihanović, 2013). As the first arrival of dense water is associated with the water generated at the beginning and in the middle of the three-week cold outbreak (i.e. at the beginning of February), one may estimate that the time needed for dense water to come to the pit is about two weeks. This is two times shorter than the normal arrival time estimated from multidecadal time series (Vilibić, 2003). These estimates are based on the observations of the bottom density current made by an ARGO profiler. The float was profiling along the northwestern perimeter of the Jabuka Pit in mid- and late February, and it detected the first arrival of the dense water on 18 February 2012 (Vilibić and Mihanović, 2013). 


\subsection{Preconditioning and long-term changes}

As estimated salinity increase due to evaporation is on the order of 0.1 , the observed high salinities at all dense water formation sites, particularly in the inner Croatian waters, should be a result of a preconditioning. Indeed all of 2011 was characterized by very dry and warm conditions in western and southern Europe (NOAA/NCDC and WMO climate reports), especially over the eastern Adriatic, where the driest year ever was recorded (climate report from Meteorological and Hydrological Service of Croatia, available at http://klima.hr). Also, the monthly runoff of the largest Adriatic river, Po River, was constantly below the respective average (about $-25 \%$ overall) throughout a whole year, from April 2011 to March 2012. This is particularly relevant to the inner eastern coastal waters, where freshwater load coming largely through submarine karstic springs was very low (stations PC, MS, ZD, DR); therefore, high salinity preceded the cooling episode in the winter of 2012.

Simultaneously, the advection of saline waters over Palagruža Sill towards the open middle and north Adriatic in the summer of 2011 (see station JP in Fig. 2a) increased the salinity at all open dense water formation sites by about 0.3 . As coastal waters were absent, these high salinity waters reached the northernmost Adriatic shelf areas and intruded into the coastal eastern Adriatic.

The preconditioning to the dense water formation ended with warmer- and saltier-than-average waters, rapidly changing to colder than average during the three weeks of bora outbreak. The synoptic setting in the atmosphere was persistent for almost three weeks of the cold outbreak. It included several deep cyclones traversing the Mediterranean, mesoscale cyclones developing over the middle and south Adriatic and a high pressure system stretching from Scandinavia to western Europe. This represents a classical blocking situation (Lejenäs, 1989), occurring with such intensity over the Adriatic once every few decades. To be precise, such persistence in cold outbreaks over the Adriatic was observed previously in 1929 and 1956 (Penzar et al., 2001). The winter of 1929 was so severe that bottom waters in the Gulf of Trieste cooled down to $3.95^{\circ} \mathrm{C}$, with observed salinity equalling 38.15 (Vatova, 1934). The strength of dense water formation during the winter of 1956 was measured at the deep JP station surveyed on 26 April 1956, where temperature and salinity at $240 \mathrm{~m}$ equalled $9.27^{\circ} \mathrm{C}$ and 38.31 , respectively, resulting in potential density anomaly of $29.67 \mathrm{~kg} \mathrm{~m}^{-3}$. One should note that both past extreme dense water formations (in 1929 and 1956) were characterized by much lower salinities, as preconditioning was presumably different, with much higher precipitation rates and river runoffs and cooler climate preceding the dense water formation.

The available long-term series in the coastal eastern Adriatic (Fig. 6) and the Gulf of Trieste reveal the extremeness of the winter 2012 cooling event and dense water generation. One may notice that density anomaly was the highest ob-
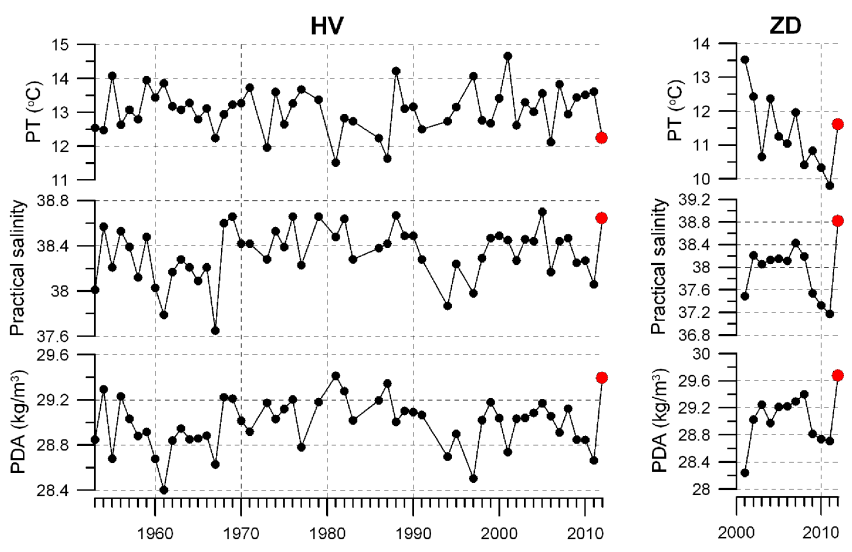

Fig. 6. Long-term series of potential temperature (PT), practical salinity and potential density anomaly (PDA) collected at stations $\mathrm{HV}$ and ZD (see Fig. 1 for station locations), at the maximum density level between 1 February and 1 April. These dates are chosen as the maximum density in the deep Adriatic Sea occurs during this interval. Red circles denote the year 2012.

served in both examined long-term series, even in the coastal middle Adriatic area which was not as exposed to cooling as the coastal northern Adriatic. The observed maximum density anomaly at station HV (Fig. 6) in the 1952-2012 interval was a combination of high salinity and low temperature values, although both temperature and salinity did not reach record-breaking values. A $10 \mathrm{yr}$-long series at station ZD (Fig. 6) shows the importance of very high salinity to the observed record-breaking density, since temperatures were close to average winter values at this station.

Long-term sea temperature series in the Gulf of Trieste are available in the Port of Trieste (at the depth of $2 \mathrm{~m}$ ). The series consisting of one daily observation in the late morning started in 1934 and are free of gaps since 1946 (CNRISMAR archives, unpublished data). Although it is false to compare different historical synoptic events purely on specific parameters, it can be noted that the sea temperatures at $2 \mathrm{~m}$ depth were below $4.0^{\circ} \mathrm{C}$ during February 2012 (minimum of $3.8^{\circ} \mathrm{C}$ on 12 February). This "threshold" was previously reached in 1963 (minimum of $4.0^{\circ} \mathrm{C}$ ) and during several days in early February 1942, when the absolute minimum of $3.2^{\circ} \mathrm{C}$ was measured. Thus, we may deduce that near-sea-surface temperature in the Port of Trieste reached "the second lowest" yearly value in February 2012. Unfortunately, no similar salinity record is available.

Additionally, the analysis of joined collection of CTD vertical profiles taken in the Gulf of Trieste between January and March since 1996 also confirms that the dense water formation event in February 2012 was exceptional. Field campaigns were conducted by ARPA-FVG and OGS in Italy, and NIB-MBS in Slovenia. The data from 133 CTD stations until 2011, with temperature, salinity and potential density anomaly values extracted every $1 \mathrm{~m}$, show that the lowest 
mean temperatures are found in February $\left(8.55 \pm 1.33^{\circ} \mathrm{C}\right)$. Mean values of salinity in January $(37.35 \pm 1.44)$ and February $(37.33 \pm 1.38)$ are similar and are higher than those measured in March (37.22 \pm 1.83$)$. The month with the largest density anomalies is February $\left(29.02 \pm 1.11 \mathrm{~kg} \mathrm{~m}^{-3}\right)$, followed by January $\left(28.88 \pm 1.11 \mathrm{~kg} \mathrm{~m}^{-3}\right)$ and March $\left(28.87 \pm 1.51 \mathrm{~kg} \mathrm{~m}^{-3}\right)$. Between 1996 and 2011 the highest potential density anomaly was measured on 18 February $2005\left(30.12 \mathrm{~kg} \mathrm{~m}^{-3}\right)$. On the other hand, in February 2012 mean potential density anomaly at 45 CTD stations was $30.23 \mathrm{~kg} \mathrm{~m}^{-3}\left( \pm 0.38 \mathrm{~kg} \mathrm{~m}^{-3}\right)$, with temperature $5.30 \pm 1.17^{\circ} \mathrm{C}$ and salinity $38.28 \pm 0.50$, which is close to the previous 1929 maximum value $\left(30.30 \mathrm{~kg} \mathrm{~m}^{-3}\right.$; Vatova, 1934). Potential density anomaly went up to a maximum of $30.59 \mathrm{~kg} \mathrm{~m}^{-3}$, observed on 15 February 2012 (station TS, see Fig. 1 and Table 1), which is, according to available observations in the gulf, the new record value. All this confirms once more the strength of the extreme cooling event in JanuaryFebruary 2012.

The observed difference in temperature and salinity over multidecadal and centurial timescales may be associated with ongoing climate changes, observable in a positive trend of the Adriatic salinity and upper-layer temperature (Vilibić et al., 2013), driven by positive E-P-R (E - evaporation, P - precipitation, $\mathrm{R}$ - rivers) and heat flux trends observed over the Adriatic. The changes in coastal regions are found and projected to be more rapid (Vilibić et al., 2013): the decrease in freshwater coastal input in the Adriatic, resulting in salinity and density trends higher in coastal regions than in the open Adriatic, may weaken Adriatic-Ionian thermohaline circulation and therefore change the BiOS variability. Climate projections for the end of the 21st century give additional warming of surface Adriatic waters by about $2.5^{\circ} \mathrm{C}$ and salinity increase of about 0.5 (Tsimplis et al., 2008), which will be reflected in the characteristics of the formed dense water in the future and has already been detected in the last $60 \mathrm{yr}$ of available observations (Vilibić et al., 2013). This will presumably result in more saline and warmer dense waters, which will replace and change thermohaline properties of the present deep Adriatic and Mediterranean waters.

On the other hand, atmospheric blocking situations and intensity of cold air outbreaks over southern Europe are projected to increase in the 21st century (Vavrus et al., 2006). This may result in more frequent occurrence of prolonged dense water formation episodes like in 2012. These changes are quite important, as the dense water formation brings the oxygen to deep ocean layers, necessary especially within biodiversity niches such as the Jabuka Pit, but also important for the whole deep Mediterranean. Finally, they will influence internal processes in the Ionian Sea and the BiOS, thus affecting circulation patterns and pathways of water masses, and possibly impacting the future interplay in dense water formation between the Adriatic and Aegean seas.
Acknowledgements. We are indebted to all the oceanographers, crew members and technicians who collected and processed the observations. The data collected from the ARGO floats were made freely available by the International Argo Program and the national programs that contribute to it. The Argo Program is part of the Global Ocean Observing System. We are grateful to A. Coluccelli (DISVA, Università Politecnica delle Marche, Ancona, Italy) for ROMS operational setup and part of output processing, and to M. Deserti, T. Paccagnella and A. Valentini (SIMC-ARPA-EMR, Bologna, Italy) for the COSMO/ROMS forecasts. The support for the study was received through the Ministry of Science, Education and Sports of the Republic of Croatia (grants 001-0013077-1122, 119-1193086-3085, 119-1191189-1228 and 004-1193086-3036). A. Bergamasco and A. Boldrin acknowledge the partial support received by the Veneto Region (Regional Law no. 15, 12 July 2007, Projects SISOE: Integrated System for Oceanographic and Ecological monitoring of the Adriatic Sea and MARINA), while S. Carniel is grateful to the FIRB Project support. V. Malačič is indebted to the group performing the national monitoring program (under the EU Water Framework Directive), funded by the Slovenian Agency of Environment, and to the research program funded by the Ministry of Higher Education and Technology of Slovenia (contract no. P1-0237). M. Celio is indebted to the marine coastal waters monitoring program of the Friuli Venezia Giulia Region under the EU Water Framework Directive 2000/60/CE and D. M. $260 / 10$. Comments raised by two anonymous reviewers are highly appreciated.

\section{Edited by: M. Hoppema}

\section{References}

Allen, S. E. and Durrieu de Madron, X.: A review of the role of submarine canyons in deep-ocean exchange with the shelf, Ocean Sci., 5, 607-650, 2009,

http://www.ocean-sci.net/5/607/2009/.

Artegiani, A. and Salusti, E.: Field observation of the flow of dense water on the bottom of the Adriatic Sea during the winter of 1981, Oceanol. Acta, 10, 387-391, 1987.

Artegiani, A., Bregant, D., Paschini, E., Pinardi, N., Raicich, F., and Russo, A.: The Adriatic Sea general circulation. Part I: airsea interactions and water mass structure, J. Phys. Oceanogr., 27, 1492-1514, 1997a.

Artegiani, A., Bregant, D., Paschini, E., Pinardi, N., Raicich, F., and Russo, A.: The Adriatic Sea general circulation, Part II: Baroclinic Circulation Structure, J. Phys. Oceanogr., 27, 1515-1532, 1997b.

Beg-Paklar, G., Isakov, V., Koracin, D., Kourafalou, V., and Orlić, M.: A case study of bora-driven flow and density changes on the Adriatic shelf (January 1987), Cont. Shelf Res., 21, 1751-1783, 2001.

Béranger, K., Drillet, Y., Houssais, M. N., Testor, P., BourdalléBadie, R., Alhammoud, B., Bozec, A., Mortier, L., BouruetAubertot, P., and Crépon, M.: Impact of the spatial distribution of the atmospheric forcing on water mass formation in the Mediterranean Sea, J. Geophys. Res., 115, C12041, doi:10.1029/2009JC005648, 2010.

Bergamasco, A., Oguz, T., and Malanotte-Rizzoli, P.: Modeling dense water mass formation and winter circulation in the north- 
ern and central Adriatic Sea, J. Mar. Syst., 20, 279-300, 1999.

Boldrin, A., Carniel, S., Giani, M., Marini, M., Bernardi Aubry, F., Campanelli, A., Grilli, F., and Russo, A.: Effects of bora wind on physical and biogeochemical properties of stratified waters in the northern Adriatic, J. Geophys. Res., 114, C08S92, doi:10.1029/2008JC004837, 2009.

Canals, M., Danovaro, R., Heussner, S., Lykousis, V., Puig, P., Trincardi, F., Calafat, A. M., de Madron, X. D., Palanques, A., and Sanchez-Vidal, A.: Cascades in Mediterranean submarine grand canyons, Oceanography, 22, 26-43, 2009.

Chiggiato, J. and Oddo, P.: Operational ocean models in the Adriatic Sea: a skill assessment, Ocean Sci. 4, 61-71, 2008.

Civitarese, G., Gacčić, M., Lipizer, M., and Eusebi Borzelli, G. L.: On the impact of the Bimodal Oscillating System (BiOS) on the biogeochemistry and biology of the Adriatic and Ionian Seas (Eastern Mediterranean), Biogeosciences, 7, 3987-3997, doi:10.5194/bg-7-3987-2010, 2010.

Edson, J. B.: Review of air-sea transfer processes, Proceedings on ECMWF Workshop on Ocean-Atmosphere Interactions, ECMWF, Reading, 7-24, 2009.

Fairall, C. W., Bradley, E. F., Hare, J. E., Grachev, A. A., and Edson, J. B.: Bulk parameterization of air-sea fluxes: Updates and verification for the COARE algorithm, J. Cli., 16, 571-591, 2003.

Gačić, M. Civitarese, G., Miserocchi, S., Cardin, V., Crise, A., and Mauri, E.: The open-ocean convection in the Southern Adriatic: a controlling mechanism of the spring phytoplankton bloom, Cont. Shelf Res., 22, 1897-1908, 2002.

Gačić, M., Eusebi Borzelli, G. L., Civitarese, G., Cardin, V., and Yari, S.: Can internal processes sustain reversals of the ocean upper circulation?, The Ionian Sea example, Geophys. Res. Lett., 37, L09608, doi:10.1029/2010GL043216, 2010.

Gačić, M., Civitarese, G., Eusebi Borzelli, G. L., Kovačević, V., Poulain, P.-M., Theocharis, A., Menna, M., Catucci, A., and Zarokanellos, N.: On the relationship between the decadal oscillations of the northern Ionian Sea and the salinity distributions in the eastern Mediterranean, J. Geophys. Res., 116, C12002, doi:10.1029/2011JC007280, 2011.

Gill, A. E.: Atmosphere-Ocean Dynamics, Academic Press, Orlando, 662 pp., 1982.

Grisogono, B. and Belušić, D.: A review of recent advances in understanding the meso- and microscale properties of the severe Bora wind, Tellus A, 61, 1-16, 2009.

Ivanov, V. V., Shapiro, G. I., Huthnance, J. M., Aleynik, D. L., and Golovin, P. N.: Cascades of dense water around the world ocean, Prog. Oceanogr., 60, 47-98, 2004.

Jeffries, M. A. and Craig, M. L.: A climatology of the northern Adriatic Sea's response to bora and river forcing, J. Geophys. Res., 112, C03S02, doi:10.1029/2006JC003664, 2007.

Josey, S. A.: Changes in the heat and freshwater forcing of the eastern Mediterranean and their influence on deep water formation, J. Geophys. Res., 108, C7, 3237, doi:10.1029/2003JC001778, 2003.

Lejenäs, H.: The severe winter in Europe 1941-1942 - the large circulation, cutoffs lows and blocking, Bull. Am. Meteorol. Soc., 70, 271-281, 1989.

Mantziafou, A. and Lascaratos, A.: An eddy resolving numerical study of the general circulation and deep-water formation in the Adriatic Sea, Deep-Sea Res. I, 51, 921-952, 2004.
Oddo, P. and Guarnieri, A.: A study of the hydrographic conditions in the Adriatic Sea from numerical modelling and direct observations (2000-2008), Ocean Sci., 7, 549-567, doi:10.5194/os-7549-2011, 2011.

Oddo, P., Adani, M., Pinardi, N., Fratianni, C., Tonani, M., and Pettenuzzo, D.: A nested Atlantic-Mediterranean Sea general circulation model for operational forecasting, Ocean Sci., 5, 461-473, doi:10.5194/os-5-461-2009, 2009.

Pasqual, C., Sanchez-Vidal, A., Zúñiga, D., Calafat, A., Canals, M., Durrieu de Madron, X., Puig, P., Heussner, S., Palanques, A., and Delsaut, N.: Flux and composition of settling particles across the continental margin of the Gulf of Lion: the role of dense shelf water cascading, Biogeosciences, 7, 217-231, doi:10.5194/bg-7217-2010, 2010.

Pattiaratchi, C., Hollings, B., Woo, M., and Welhena, T.: Dense shelf water formation along the south-west Australian inner shelf, Geophys. Res. Lett., 38, L10609, doi:10.1029/2011GL046816, 2011.

Penzar, B., Penzar, I., and Orlić, M.: Weather and Climate of the Croatian Adriatic (in Croatian), Nakladna kuća "Dr. Feletar", Hydrographic Institute of the Republic of Croatia, Split, 258 pp., 2001.

Pullen, J., Doyle, J. D., Haack, T., Dorman, C., Signell, R. P., and Craig, M. L.: Bora event variability and the role of air-sea feedback, J. Geophys. Res., 112, C03S18, doi:10.1029/2006JC003726, 2007.

Robinson, A. R., Leslie, W. G., Theocharis, A., and Lascaratos, A.: Mediterranean Sea circulation, in: Encyclopedia of Ocean Sciences, edited by: Steele, J. H., Thorpe, S. A., and Turekian, K. K., Elsevier, Amsterdam, 1689-1705, 2003.

Russo, A., Coluccelli, A., Iermano, I., Falcieri, F., Ravaioli, M., Bortoluzzi, G., Focaccia, P., Stanghellini, G., Ferrari, C. R., Chiggiato, J. and Deserti, M.: An operational system for forecasting hypoxic events in the northern Adriatic Sea, Geofizika, 26, 191-213, 2009.

Somot, S., Sevault, F., and Déqué, M.: Transient climate change scenario simulation of the Mediterranean Sea for the twenty-first century using a high-resolution ocean circulation model, Clim. Dyn., 27, 851-879, 2006.

Steppeler, J., Doms, G., Schättler, U., Bitzer, H. W., Gassmann, A., Damrath, U., and Gregoric G.: Meso-gamma scale forecasts using the nonhydrostatic model LM, Meteorol. Atmos., 115, 488504, 2003.

Supić, N. and Vilibić, I.: Dense water characteristics in the northern Adriatic in the 1967-2000 interval with respect to surface fluxes and Po River discharges, Estuar. Coast. Shelf Sci., 66, 580-593, 2006.

Termonia, P.: Scale selective digital filter initialization, Mon. Wea. Rev., 136, 5246-5255, 2008.

Tsimplis, M. N., Marcos, M., and Somot, S.: 21st century Mediterranean sea level rise: Steric and atmospheric pressure contributions from a regional model, Glob. Planet. Change, 63, 105-111, 2008.

Tudor, M. and Ivatek-Šahdan, S.: The case study of bura of 1st and 3rd February 2007, Meteorol. Z., 19, 2867-2882, 2010.

Vatova, A.: L'anormale regime fisico-chimico dell'Alto Adriatico nel 1929 e le sue ripercussioni sulla fauna, Thalassia I, 8, 1-49, 1934. 
Vavrus, S., Walsh, J. E., Chapman, W. L., and Portis, D.: The behavior of extreme cold air outbreaks under greenhouse warming, Int. J. Climatol., 26, 1133-1147, 2006.

Vilibić, I.: An analysis of dense water production on the North Adriatic shelf, Estuar. Coast. Shelf Sci., 56, 697-707, 2003.

Vilibić, I. and Orlić, M.: Adriatic water masses, their rates of formation and transport through the Otranto Strait, Deep-Sea Res. I, 49, 1321-1340, 2002.

Vilibić, I. and Supić, N.: Dense water generation on a shelf: the case of the Adriatic Sea, Ocean Dyn., 55, 403-415, 2005.

Vilibić, I. and Mihanović, H.: Observing the bottom density current over a shelf using an Argo profiling float, Geophys., Res, Lett., 40, 910-915, doi:10.1002/grl.50215, 2013.
Vilibić, I., Grbec, B., and Supić, N.: Dense water generation in the north Adriatic in 1999 and its recirculation along the Jabuka Pit, Deep-Sea Res. I, 51, 1457-1474, 2004.

Vilibić, I. Šepić, J., and Proust, N.: Observational evidence of a weakening of thermohaline circulation in the Adriatic Sea, Clim. Res., 55, 217-225, 2013.

Zore-Armanda, M.: Les masses d'eau de la mer Adriatique, Acta Adriat., 10, 5-88, 1963.

Zore-Armanda, M., Bone, M., Dadić, V., Morović, M., Ratković, D., Stojanoski L., and Vukadin, I.: Hydrographic properties of the Adriatic Sea from 1971 through 1983, Acta Adriat., 32, 1$547,1991$. 